\title{
Study on the Evaluation of Ecological Compensation Effect for Environmental Pollution Loss from Energy Consumption: Taking Nanjing MV Industrial Park as an Example
}

Xiuyan Han ( $\nabla$ hanxy2015@163.com )

Qufu Normal Universit Rizhao Campus https://orcid.org/0000-0002-1860-1977

Tianyi Cao

Dalian University of Technology

\section{Research Article}

Keywords: Ecological compensation effect, comprehensive evaluation, SNSM, environmental pollution loss, industrial parks

Posted Date: August 11th, 2021

DOl: https://doi.org/10.21203/rs.3.rs-681011/v1

License: (c) (1) This work is licensed under a Creative Commons Attribution 4.0 International License. Read Full License

Version of Record: A version of this preprint was published at Environmental Technology \&amp; Innovation on March 1st, 2022. See the published version at https://doi.org/10.1016/j.eti.2022.102473. 
1 Study on the Evaluation of Ecological Compensation Effect for

2 Environmental Pollution Loss from Energy Consumption:

3 Taking Nanjing MV Industrial Park as an Example

4 Xiuyan Han ${ }^{\text {a* }}$, Tianyi Cao ${ }^{\mathbf{b}}$

$5 \quad$ a School of Economics, Qufu Normal University, Rizhao 276826, China

$6{ }^{\mathrm{b}}$ School of Economics and Management, Dalian University of Technology, Dalian, Liaoning 116024 China

7 Abstract: In order to explore the effective method of the ecological compensation effect evaluation (ECEE) of 8 the environmental pollution loss (EPS) in the industrial parks, based on the literature review and the current 9 situation analysis, this paper selected four kinds of 26 evaluation indicators to build the evaluation indicators system. The spatial niche suitability model (SNSM) is reconstructed after analysis and improvement. Then, taking Nanjing MV Industrial Park as an example, SNSM and related research data were used to perform an application test of ecological compensation effect evaluation. The evaluation results showed that although the ecological compensation effect of the Nanjing MV industrial park's environmental pollution loss showed an upward trend in 2011-2018, the upward situation showed an imbalance. The effect of ecological environment compensation input status and ecological environment pollution status is significantly lagging behind. They are still the focus of future work of Nanjing MV Industrial Park. The research proved that the niche suitability model's evaluation results conform to Nanjing MV Industrial Park's actual situation. This paper's research results provide an effective quantitative analysis method for the management of ecological compensation effects in industrial parks and the improvement of ecological compensation effects. industrial parks

Acknowledgements: This work has received funding from the general project of national social science foundation of China: "Research on mechanism and supportive polices of environmental pollution cooperative governance in the process of regional integration development of the Yangtze River delta" (Approval number: 19BJL035). The author thanks the National Office for philosophy and Social Sciences for this study support.

Authors: Xiuyan Han (1974-) , Women, Born in Jiamusi of Heilongiiang province. Associate professor and doctor of management, School of economics, Qufu Normal University, research direction: energy and environmental management; Tianyi Cao (1998-) , Women, Born in Jiamusi of Heilongjiang province, master degree candidate, Faculty of Economics and Management of Dalian University of Technology. Research direction: Environmental Finance. 


\section{Introduction}

The development of China's industrial parks not only promotes the rapid economic growth, but also produces environmental pollution to a certain extent. The evaluation of ecological compensation effect of environmental pollution loss has been raised, and gradually becomes a major problem that needs to be solved (Han et al, 2019). For a long time, the problem of ecological compensation for environmental pollution loss in China's industrial parks has not been paid enough attention to, so the environmental pollution level of industrial parks has been kept at a high level. The deepening of environmental pollution will have a significant impact on the compensation effect of environmental pollution loss, ecological environment quality and sustainable development of industrial parks (Wang et al., 2019). Meanwhile, the deepening of environmental pollution will also pose a threat to people's living environment, quality of life, health and even life to some extent (Yang et al., 2019). Therefore, it is particularly important and urgent to study the evaluation method and application of ecological compensation for environmental pollution loss in industrial parks.

Overseas research on ecological compensation effect evaluation started early. In 1910, American scholar Johnson first proposed the concept of niche. In the early 1920s, Gri-nell first proposed and used the niche method in 1924. Charles Elton developed the niche method in 1927, which is mainly used to analyze ecological conditions (Barry et al., 1980). In the late 1970s, the concept of "service of nature" was first put forward by theorists, advocating that environmental polluters should make economic compensation for ecological damage (Westman et al., 1997). In the mid-1980s, the nomadic pastoralist areas in the western United States had a certain degree of damage to the ecosystem due to energy extraction and utilization, so ecological compensation effect evaluation and its application began to be studied 
assessment study on the environmental pollution and its pollution losses in American ocean and atmosphere, constructed an evaluation model, and reached valuable evaluation conclusions (Arrow et al., 1993). Since then, the research on the charging effect of ecological service system has been comprehensively developed, and the ecological compensation system has gradually become a development trend in the future (Müller, 1997). Kelly (2007) used the niche model to evaluate the ecological risks of forests in the United States. According to the latest research results, overseas evaluation of ecological compensation effect is developing towards the direction of multiple standards and technologies (Martín-López et al., 2019). The evaluation of ecological compensation effect involves more and more contents, including: road environmental pollution payment (Cuperus et al, 1996), ecological compensation of damaged watershed (Loomis et al., 2000) Rural ecological compensation (Geussens et al., 2019), land pollution ecological compensation (Loft et al., 2019), etc. In the specific evaluation process, scholars considered that the ecological compensation effect of environmental pollution loss should be evaluated in combination with social benefits (Grima et al., 2018), and the cost-effectiveness of ecological compensation mode (Liu et al., 2020) as well as environmental protection and poverty reduction objectives should be fully considered (Ola et al., 2019). It can be seen that the evaluation of ecological compensation effect in foreign countries is earlier than that in China, and a relatively systematic system of theories and methods has been formed. 21 st century, more than 20 years later than that of developed countries. Most of the studies were based on the research results and experience of overseas countries, and the theories and methods of the ecological compensation effect of environmental pollution loss suitable for China's national conditions are in urgent need of research $(\mathrm{Xu}$ and $\mathrm{Li}, 2015)$. In China, Deng et al. (2001) first proposed that ecological 

studied how to introduce ecological compensation into the environmental impact and explored its application in combination with the actual situation. Since 2010, with the rapid development of China's ecological industrial parks, more and more research results have been made on the effect of ecological compensation and the system of ecological compensation in China, mainly focusing on agriculture, grassland, water area, forest, electricity, etc. China's theorists' research on regional ecological compensation started in the early 21st century (Du 2001), and the research on Industrial Park ecological compensation started in 2013 (Wang et al., 2013). Relevant research results are as follows: Shen et al. (2018) analyzed the performance of ecological compensation in the ecological barrier area, studied the evaluation method and application of ecological performance; Jin et al. (2019) incorporated GEP into the performance evaluation and evaluation system of ecological compensation, and studied the effective method of implementing the performance of ecological compensation to promote the growth of GDP; Zeng et al. (2019) took the ecological compensation of Xilin Gol grassland as an example, studied the impacting performance of ecological compensation performance, and explored effective ways to improve ecological compensation performance. There are still many studies in China that focus on environmental pollution and ecological compensation in urbanization. (Han et al., 2018, 2019; Liu et al. , 2020); Some researchers used niche models to evaluate urban forest landscape quality (Han et al., 2021).

From the above literature review, research on the evaluation of ecological compensation effects at home and abroad is in the development stage, and the overseas ecological compensation effect evaluation adopts the name of "ecosystem service payment". Although the theory and method system of ecological compensation effect evaluation has formed, due to differences in social systems, ecological compensation concepts, and compensation subjects, the theories and methods of ecological compensation effect evaluation 
cannot be directly applied in China. In China, there are relatively few research results on ecological compensation and evaluation of ecological compensation effect. Most of the research on this problem is not in-depth, and the existing research results cannot meet the needs of the practice of evaluating the effect of ecological compensation for environmental pollution losses in China's industrial parks, and there is an urgent need for scientific and effective methods for evaluating the effects of ecological compensation for environmental pollution losses and application examples. Therefore, it is very important and urgent to study the comprehensive evaluation method and its application of ecological compensation effect of environmental pollution loss in Nanjing MV Industrial Park.

\section{Materials and Methods}

\subsection{Construction of evaluation indicators system and definition of evaluation standard}

\subsubsection{Selection of evaluation indicators and construction of evaluation indicators system}

In order to achieve the comprehensive evaluation of the ecological compensation effect of environmental pollution loss in industrial parks, it is necessary to select the comprehensive evaluation indicators to build the evaluation indicators system of the ecological compensation effect of environmental pollution loss in industrial parks (Bundy et al., 2019). Based on comprehensive analysis, fully consider the actual situation of ecological compensation for environmental pollution loss in China's industrial parks, according to the requirements of the "Evaluation Method of Ecological Compensation Effect for Environmental Pollution Treatment of Nanjing MV Industrial Park" and the latest research results of China' experts (Guo and Li, 2014; Gong and Chen, 2019; Teng, 2020), economic effect, ecological compensation, ecological environmental pollution, and ecological environmental pollution treatment were selected, with a total of 26 comprehensive evaluation indicators. These evaluation indicators comprehensively reflect the ecological compensation effect of pollution treatment in industrial parks. According to the selected specific 
112 the environmental pollution treatment in industrial parks is set up in Table 1.

113 Table 1 Comprehensive evaluation indicators system of ECEE of energy consumption pollution treatment in Nanjing MV Industrial Park

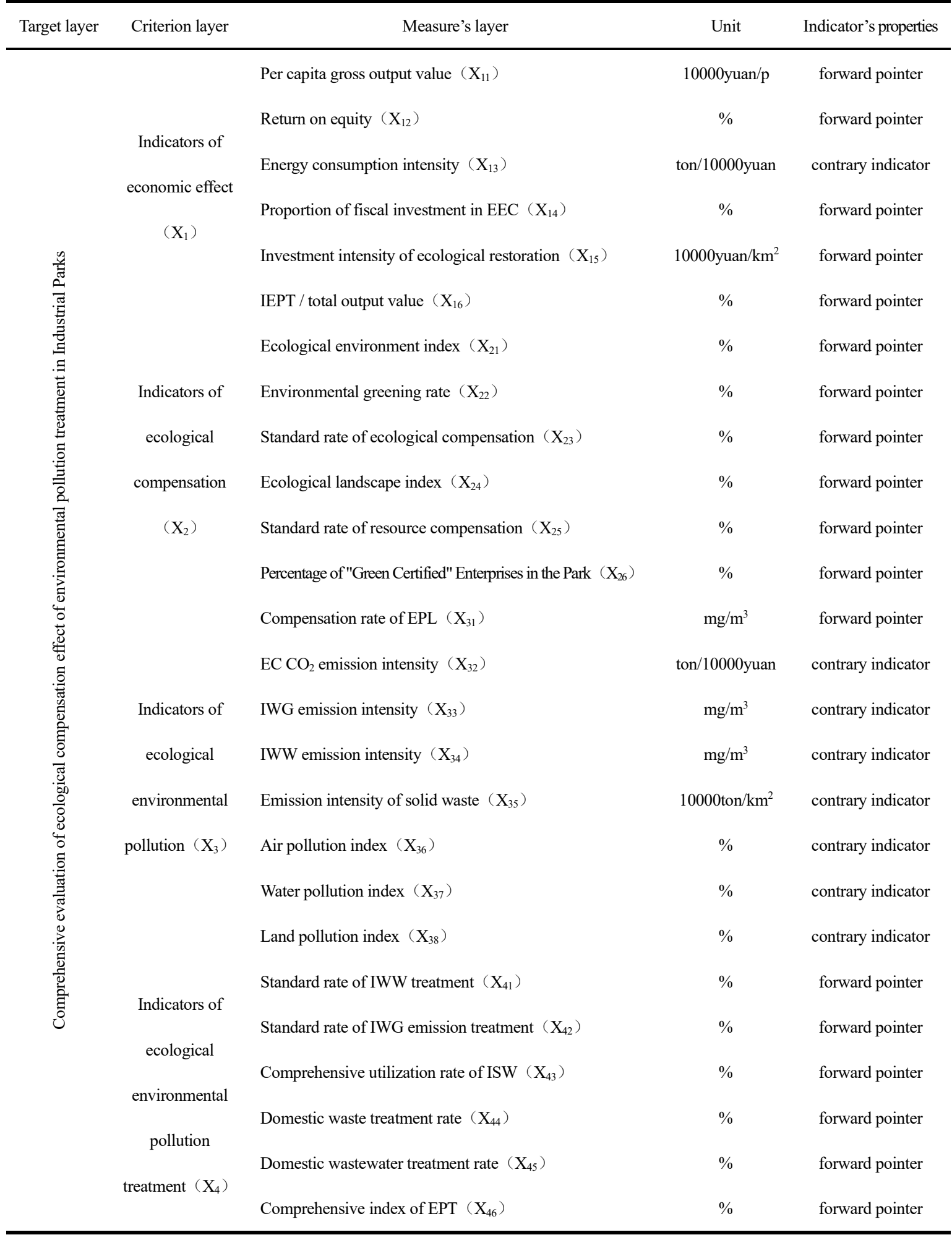


effect reflect the status of the impact of environmental pollution loss ecological compensation on the economic effect. Environmental pollution treatment and ecological compensation do not affect the economic effect is the basic requirement, so that this paper selected indicators of per capita gross output value and return on equity; Energy consumption intensity is the ratio of energy consumption to the total industrial output value of the same caliber. It is an contrary indicator and strives to reduce energy consumption without reducing the total industrial output value; the proportion of fiscal investment in ecological environment compensation refers to the proportion of fiscal funds in the total investment for ecological restoration and environmental pollution treatment of the industrial park; investment intensity of ecological restoration refers to the required amount of investment in restoration or improvement of industrial output value in the same period; indicators of ecological compensation reflects the ecological quality status of the industrial park, and ecological environment index is the ratio of the ecological index environmental greening rate is the ratio of the green area in the park to the total area; the standard rate of ecological compensation refers to the ratio of the amount of ecological compensation (or the number of projects that meet the standard) to the total ecological compensation standard (the total number of ecological compensation projects); the ecology landscape index refers to the ratio of the current value of 
the main landscape index to the value of the previous period. The average value of the landscape diversity index, landscape richness index, landscape evenness index, landscape aggregation index and landscape naturalness index in the evaluation is used to measure ecology landscape status; the rate of resource compensation compliance refers to the ratio of the total amount of funds that have been compensated for main resource consumption or pollution in the park to the total amount of compensation that should be compensated according to the standard. Consumption of energy and polluted water and land resources; the percentage of "green certification" enterprises in the park refers to the ratio of the number of enterprises that have passed the prescribed green certification to the total number of enterprises; the indicators of ecological environment pollution reflects the degree of ecological environmental degradation, the compensation rate of EPL is the ratio of the total value of compensation for various forms of environmental pollution treatment and restoration in the park to the total environmental pollution loss measurement caused by energy consumption and pollution; energy consumption $\mathrm{CO}_{2}$ emission intensity refers the ratio of the park energy consumption $\mathrm{CO}_{2}$ emissions to the total output value in the same period in the fiscal year; industrial waste gas emission intensity, industrial wastewater emission intensity, and emission intensity of solid waste are the ratios between the actual emissions of waste gas, wastewater, and solid waste and the emission standards. The emissions of multiple pollutants are calculated by weighted average; the air pollution index, water pollution index and land pollution index are the ratios of the pollution index of the current period to the pollution index of the previous period. Multiple Pollutions are calculated using the weighted average method, and this article used the pollution indexes calculated by the park; the indicators of ecological environmental pollution treatment reflect the effect of environmental pollution restoration. The standard rate of IWW treatment and the standard rate of IWG emission treatment are the degrees to which the corresponding pollution index reaches the required standard; the comprehensive 
utilization rate of ISW refers to the ratio of the solid waste discharged by industrial production that can be fully utilized and generate value to the total discharge; the domestic waste treatment rate refers to the ratio of the waste discharged by the employees in the park and reach the degree of pollution-free through treatment; the domestic wastewater treatment rate refers to the ratio of the wastewater discharged by the employees in the park and reaches the degree of pollution-free through treatment; the comprehensive index of EPT refers to the weighted average of the air pollution index, water pollution index and land pollution index of the park, and the data is from the results calculated by the industrial park.

\subsubsection{Collection of research data}

In order to explain the evaluation method of the ecological compensation effect of environmental pollution loss in Industrial Park, MV Industrial Park in Nanjing was selected as the evaluation object of the ecological compensation effect. Nanjing MV Industrial Park is located in Jiangning High-tech Development Zone, covering 52.98 square kilometers. There are 52 production-oriented enterprises in the park. By the end of 2018, there were 3,263,200 employees, total registered capital of 4.21856 billion yuan, a total investment of 12.55218 billion yuan, a realized output value of 15.12645 , and a tax of 1.5321 .8 billion yuan. Nanjing MV Industrial Park was founded in 1998. In 2001, the planned production capacity was realized, and comprehensive environmental treatment work began since the environmental pollution situation was highlighted. According to the statistical data, production and operation data, and the research and investigation results of Nanjing MV Industrial Park, the basic data of 26 comprehensive evaluation indicators of Nanjing MV Industrial Park from 2011 to 2018 are collected and sorted out in Table 2. 


\begin{tabular}{|c|c|c|c|c|c|c|c|c|c|}
\hline Criterion layer & Measure's layer & 2011 & 2012 & 2013 & 2014 & 2015 & 2016 & 2017 & 2018 \\
\hline \multirow{3}{*}{$\begin{array}{l}\text { Indicators of } \\
\text { economic }\end{array}$} & $\mathrm{X}_{11}$ & 10.3518 & 10.5728 & 10.8827 & 11.2474 & 12.1829 & 13.2736 & 14.9816 & 16.3217 \\
\hline & $\mathrm{X}_{12}$ & 19.87 & 21.28 & 22.36 & 20.41 & 18.37 & 25.26 & 26.28 & 28.37 \\
\hline & $\mathrm{X}_{13}$ & 0.9218 & 0.8928 & 0.8521 & 0.7218 & 0.6927 & 0.6527 & 0.5826 & 0.4981 \\
\hline \multirow{2}{*}{$\begin{array}{l}\text { effect } \\
\left(X_{1}\right)\end{array}$} & $\mathrm{X}_{14}$ & 46.68 & 46.96 & 47.05 & 47.37 & 47.65 & 48.96 & 48.56 & 48.06 \\
\hline & $\mathrm{X}_{15}$ & 375 & 371 & 388 & 398 & 432 & 438 & 446 & 450 \\
\hline \multirow{5}{*}{$\begin{array}{l}\text { Indicators of } \\
\text { ecological } \\
\text { compensation } \\
\quad\left(\mathrm{X}_{2}\right)\end{array}$} & $\mathrm{X}_{16}$ & 1.5728 & 1.6528 & 1.6829 & 1.6518 & 1.7927 & 1.7538 & 1.8927 & 2.0137 \\
\hline & $\mathrm{X}_{21}$ & 91.38 & 98.74 & 111.96 & 132.15 & 142.18 & 158.76 & 178.38 & 176.67 \\
\hline & $\mathrm{X}_{22}$ & 23.78 & 24.28 & 24.89 & 25.18 & 25.28 & 26.28 & 28.32 & 30.28 \\
\hline & $\mathrm{X}_{23}$ & 91.57 & 92.09 & 92.65 & 93.18 & 93.67 & 94.22 & 95.62 & 95.12 \\
\hline & $\mathrm{X}_{24}$ & 75.18 & 76.29 & 78.29 & 80.28 & 82.18 & 88.27 & 89.27 & 91.26 \\
\hline \multirow{9}{*}{$\begin{array}{l}\text { Indicators of } \\
\text { ecological } \\
\text { environmental } \\
\text { pollution } \\
\quad\left(\mathrm{X}_{3}\right)\end{array}$} & $\mathrm{X}_{25}$ & 87.13 & 87.58 & 88.06 & 88.64 & 88.89 & 89.05 & 89.89 & 90.32 \\
\hline & $\mathrm{X}_{26}$ & 94.05 & 94.75 & 95.67 & 95.96 & 96.16 & 97.87 & 97.32 & 97.28 \\
\hline & $\mathrm{X}_{31}$ & 66.19 & 66.69 & 68.76 & 69.28 & 68.32 & 70.27 & 72.08 & 80.32 \\
\hline & $\mathrm{X}_{32}$ & 2.1027 & 2.0527 & 1.9627 & 1.8236 & 1.7528 & 1.6018 & 1.5281 & 1.0827 \\
\hline & $\mathrm{X}_{33}$ & 0.5165 & 0.4792 & 0.4306 & 0.3963 & 0.3625 & 0.3179 & 0.2843 & 0.3026 \\
\hline & $\mathrm{X}_{34}$ & 1.2836 & 1.2134 & 1.1937 & 1.1256 & 1.0736 & 0.8724 & 0.6826 & 0.4825 \\
\hline & $\mathrm{X}_{35}$ & 283.26 & 248.25 & 210.36 & 183.72 & 150.57 & 102.48 & 78.28 & 49.54 \\
\hline & $\mathrm{X}_{36}$ & 213.39 & 182.28 & 150.37 & 120.28 & 107.39 & 82.29 & 65.35 & 50.32 \\
\hline & $\mathrm{X}_{37}$ & 110.38 & 98.28 & 73.29 & 59.38 & 52.39 & 50.27 & 49.29 & 48.32 \\
\hline \multirow{3}{*}{$\begin{array}{l}\text { Indicators of } \\
\text { ecological }\end{array}$} & $\mathrm{X}_{38}$ & 253.92 & 221.39 & 198.29 & 178.25 & 148.27 & 98.28 & 70.28 & 58.29 \\
\hline & $\mathrm{X}_{41}$ & 66.28 & 68.37 & 70.27 & 72.39 & 74.39 & 75.62 & 78.39 & 86.28 \\
\hline & $\mathrm{X}_{42}$ & 70.28 & 74.28 & 76.29 & 78.36 & 77.28 & 78.38 & 79.38 & 80.38 \\
\hline environmental & $\mathrm{X}_{43}$ & 69.78 & 72.49 & 74.82 & 77.29 & 79.38 & 80.73 & 82.39 & 84.29 \\
\hline pollution & $\mathrm{X}_{44}$ & 68.39 & 69.38 & 71.29 & 75.38 & 78.38 & 82.38 & 89.32 & 91.02 \\
\hline treatment & $\mathrm{X}_{45}$ & 75.28 & 79.37 & 82.39 & 85.28 & 87.38 & 89.27 & 90.27 & 91.67 \\
\hline$\left(\mathrm{X}_{4}\right)$ & $\mathrm{X}_{46}$ & 44.84 & 51.84 & 78.78 & 96.47 & 141.22 & 156.34 & 161.22 & 165.47 \\
\hline
\end{tabular}

\subsubsection{Definition of evaluation standard}

The Chinese government has formulated relevant laws and regulations on environmental pollution, defined the specific evaluation indicators selected and the evaluation standards for ecological 

evaluation index is shown in Table 3 .

\begin{tabular}{|c|c|c|c|c|c|c|}
\hline No. & Indicator's name & Leve I & Level II & LevelIII & LevelIV & Level V \\
\hline 1 & Per capita gross output value $\left(\mathrm{X}_{11}\right)$ & $>17$ & $10-17$ & $8-10$ & $5-8$ & $<5$ \\
\hline 2 & Return on equity $\left(\mathrm{X}_{12}\right)$ & $>30$ & $20-30$ & $10-20$ & $5-10$ & $<5$ \\
\hline 3 & Energy consumption intensity $\left(X_{13}\right)$ & $0-0.5$ & $0.5-1.0$ & $1.0-1.5$ & $1.5-2.0$ & $>2$ \\
\hline 4 & Proportion of fiscal investment in EEC $\left(\mathrm{X}_{14}\right)$ & $>50$ & $40-50$ & $30-40$ & $20-30$ & $<20$ \\
\hline 5 & Investment intensity of ecological restoration $\left(\mathrm{X}_{15}\right)$ & $>500$ & $350-500$ & $200-350$ & $100-200$ & $<100$ \\
\hline 6 & IEPT / total output value $\left(\mathrm{X}_{16}\right)$ & $>2.5$ & $2.0-2.5$ & $1.5-2.0$ & $1-1.5$ & $<1$ \\
\hline 7 & Ecological environment index $\left(\mathrm{X}_{21}\right)$ & $>200$ & $150-200$ & $100-150$ & $50-100$ & $<50$ \\
\hline 8 & Environmental greening rate $\left(\mathrm{X}_{22}\right)$ & $>32$ & $20-32$ & $10-20$ & $5-10$ & $<5$ \\
\hline 9 & Standard rate of ecological compensation $\left(\mathrm{X}_{23}\right)$ & $90-100$ & $80-90$ & $70-80$ & $60-70$ & $<60$ \\
\hline 10 & Ecological landscape index $\left(\mathrm{X}_{24}\right)$ & $>200$ & $150-200$ & $100-150$ & $50-100$ & $<50$ \\
\hline 11 & Standard rate of resource compensation $\left(\mathrm{X}_{25}\right)$ & $90-100$ & $80-90$ & $70-80$ & $60-70$ & $<60$ \\
\hline 12 & Percentage of "Green Certified" Enterprises in the Park $\left(\mathrm{X}_{26}\right)$ & $90-100$ & $80-90$ & $70-80$ & $60-70$ & $<60$ \\
\hline 13 & Compensation rate of EPL $\left(\mathrm{X}_{31}\right)$ & $95-100$ & $80-95$ & $70-80$ & $60-70$ & $<60$ \\
\hline 14 & $\mathrm{EC} \mathrm{CO}_{2}$ emission intensity $\left(\mathrm{X}_{32}\right)$ & $0-1$ & $1-1.5$ & $1.5-2.0$ & $2-2.5$ & $>2.5$ \\
\hline 15 & IWG emission intensity $\left(\mathrm{X}_{33}\right)$ & $0-0.25$ & $0.25-0.5$ & $0.5-0.75$ & $0.75-0.1$ & $>1$ \\
\hline 16 & IWW emission intensity $\left(X_{34}\right)$ & $0-0.5$ & $0.5-1$ & $1-1.5$ & $1.5-2$ & $>2$ \\
\hline 17 & Emission intensity of solid waste $\left(\mathrm{X}_{35}\right)$ & $0-50$ & $50-200$ & $200-350$ & $350-500$ & $>500$ \\
\hline 18 & Air pollution index $\left(\mathrm{X}_{36}\right)$ & $0-50$ & $50-100$ & $100-200$ & $200-300$ & $>300$ \\
\hline 19 & Water pollution index $\left(\mathrm{X}_{37}\right)$ & $0-50$ & $50-100$ & $100-200$ & $200-300$ & $>300$ \\
\hline 20 & Land pollution index $\left(\mathrm{X}_{38}\right)$ & $0-50$ & $50-100$ & $100-200$ & $200-300$ & $>300$ \\
\hline 21 & Standard rate of IWW treatment $\left(\mathrm{X}_{41}\right)$ & $85-100$ & $75-85$ & $60-75$ & $40-60$ & $<40$ \\
\hline 22 & Standard rate of IWG emission treatment $\left(\mathrm{X}_{42}\right)$ & $85-100$ & $75-85$ & $60-75$ & $40-60$ & $<40$ \\
\hline 23 & Comprehensive utilization rate of ISW $\left(\mathrm{X}_{43}\right)$ & $85-100$ & $75-85$ & $60-75$ & $40-60$ & $<40$ \\
\hline 24 & Domestic waste treatment rate $\left(\mathrm{X}_{44}\right)$ & $90-100$ & $80-90$ & $70-80$ & $50-70$ & $<50$ \\
\hline 25 & Domestic wastewater treatment rate $\left(\mathrm{X}_{45}\right)$ & $90-100$ & $80-90$ & $70-80$ & $50-70$ & $<50$ \\
\hline 26 & Comprehensive index of EPT $\left(\mathrm{X}_{46}\right)$ & $>200$ & $150-200$ & $100-150$ & $50-100$ & $<50$ \\
\hline
\end{tabular}


at home and abroad, combining with the development planning and actual situation of China's industrial

parks, taking the specific comprehensive evaluation coefficient of the ecological compensation effect of environmental pollution loss are subdivided into five levels: excellent $[0.9,1]$, good $[0.8,0.9)$, medium $[0.7,0.8)$, qualified $[0.6,0.7)$, unqualified $[0,0.6)$. According to the requirements of national environmental failures.

\subsection{Analysis of traditional niche model} the level of ecological compensation effect by calculating the niche suitability of evaluation indicators

211 (Julián et al., 2019). The quantitative indicators of each ecological factor are defined as follows: $x_{1}(t), x_{2}(t), \cdots, x_{n}(t), x_{i}(t) \in I_{i}, I_{i}$ is the variation range of the $i$ th ecological factor that can be expressed as: $I_{i}=\left[a_{i}, b_{i}\right],(i=1,2, \cdots, n)$. Then, the range of ecological factor can be expressed as: $E=I_{1} \times I_{2} \times$ $\cdots \times I_{n}=\prod_{i=1}^{n} I_{i} . \mathrm{E}$ is a subset of N-dimensional ecological factor $E^{n}$, if the niche function is a nonnegative N-dimensional function: $f\left(X_{i}\right)=f\left(x_{1}(t), x_{2}(t), \cdots, x_{n}(t)\right)$, then niche $\mathrm{N}$ of this population 
can be expressed as:

$$
N=\left\{X_{t} \mid f\left(X_{t}\right)>0, X_{\mathrm{t}}=\left(x_{1}(t), x_{2}(t), \cdots, \quad x_{\mathrm{n}}(t)\right)\right\}, \quad N \cap E \neq \Phi
$$

According to the theory of ecology, niche suitability interval is $(0,1)$. The greater the value, the higher the degree to which ecological factors meet ecological needs (Basille et al., 2008). The optimum value of ecological factors is denoted as: $X_{\alpha}=\left(x_{1}(\alpha), x_{2}(\alpha), \cdots, x_{n}(\alpha)\right), X_{t} \in E$, then; the niche suitability of ecological factors is denoted as:

$$
F=\phi\left(X_{\alpha}, X_{t}\right), X_{\alpha} \in N, X_{t} \in E
$$

According to the different meanings of $\phi$, niche suitability functions of ecological factors have different connotations. According to relevant theories of ecology, the traditional niche model has niche suitability model $\left(\mathrm{F}_{\mathrm{t}}\right)$ and limit factor model $\left(F_{\min -t}\right)$ (Qin et al., 2011). The following two basic models of niche evaluation are introduced respectively.

\subsubsection{Average operator model $\left(F_{t}\right)$}

If the suitability of ecological factors in the industrial park in the time period $t$ is expressed as $\mathrm{F}_{\mathrm{t}}$, then the corresponding average operator niche suitability model is expressed as:

$$
F_{t}=\frac{1}{n} \sum_{i=1}^{n} \frac{\delta_{\text {min }}+\alpha \times \delta_{\max }}{\delta_{i t}+\alpha \times \delta_{\max }}=\frac{1}{n} \sum_{i=1}^{n} \frac{\min \left\{\left|x_{i}^{\prime}(t)-x_{i}^{\prime}(\alpha)\right|\right\}+\alpha \times \max \left\{\left|x_{i}^{\prime}(t)-x_{i}^{\prime}(\alpha)\right|\right\}}{\mid x_{i}^{\prime}(t)-x_{i}^{\prime}(\alpha)+\alpha \times \max \left\{\left|x_{i}^{\prime}(t)-x_{i}^{\prime}(\alpha)\right|\right\}}
$$

In the formula: $\delta_{i t}=\left|x_{i}^{\prime}(t)-x_{i}^{\prime}(\alpha)\right|, \quad(i=1,2, \cdots, n ; \quad \mathrm{t}=1,2, \cdots, \mathrm{m})$

$$
\begin{aligned}
& \delta_{\text {max }}=\max \left\{\delta_{i t}\right\}=\left\{\left|x_{i}^{\prime}(t)-x_{i}^{\prime}(\alpha)\right|\right\} \\
& \delta_{\text {min }}=\min \left\{\delta_{i t}\right\}=\left\{\left|x_{i}^{\prime}(t)-x_{i}^{\prime}(\alpha)\right|\right\}
\end{aligned}
$$

$\alpha$ is the model parameter, and the value range of $\alpha$ is: $(0 \leq \alpha \leq 1)$. The calculation results of the model can be adjusted by taking the value of the model parameters according to the changes of environmental conditions. Under normal circumstances, $x_{t}(\alpha)$ take the maximum value in each evaluation result. 
If the suitability of ecological factors in time period $t$ is expressed as: $F_{\min -t}$, since the minimum value of the factor is taken in the above equation, and the value is limited so that it is called the limiting factor model. The specific formula is:

$$
F_{\min -t}=\min \left\{\left(x_{1}^{\prime}(t) / x_{1}^{\prime}(\alpha)\right),\left(x_{2}^{\prime}(t) / x_{2}^{\prime}(\alpha)\right), \cdots,\left(x_{n}^{\prime}(t) / x_{n}^{\prime}(\alpha)\right)\right\}
$$

In the above equation, $x_{i}(t)$ is the measured value of the $i_{\text {th }}$ ecological factor, $x_{i}(\alpha)$ is the optimal value of the $\mathrm{i}_{\text {th }}$ ecological factor, $\alpha$ is the model parameter, the value range and other conditions are the same as above. This model is often used to evaluate the relationship between the most important limiting factors and their optimal values.

\subsection{Construction of comprehensive evaluation model of niche suitability}

According to niche theory and method, the evaluation indicators are expressed as follows: $x_{1}, x_{2}, \cdots, x_{n}$. Considering the time series of each evaluation indicator, the observed values constitute the ecological matrix of $m \times n$ dimension: $(i=1,2, \cdots, m ; t=1,2, \cdots, n)$. In order to build a comprehensive evaluation model of spatial niche suitability for ecological compensation effect, the generalized relational grade of gray theory is introduced to calculate the niche of ecological factors (Yang, et al., 2018), and the comprehensive evaluation model of niche suitability is constructed by using the weighted evaluation values of absolute niche suitability model and relative niche suitability model. Among them: the absolute niche suitability model is represented by $\varepsilon_{t \alpha}$ and the relative niche suitability model is represented by $\gamma_{t \alpha}$. In order to reduce the data distortion caused by shock wave interference, buffer operator is introduced to eliminate the shock wave interference. Let $\mathrm{d}$ be the average weakening buffer operator (AWBO) (Li, et al., 2019). The first-order buffer operator of the actual value of ecological factors can be expressed as: 


$$
X_{i t} d_{t}=\left(\left(\sum_{t=1}^{n} x_{i t}\right) \cdot d_{1},\left(\sum_{t=2}^{n} x_{i t}\right) \cdot d_{2}, \cdots,\left(\sum_{t=n}^{n} x_{i t}\right) \cdot d_{n}\right),(i=1,2, \cdots, m ; \quad t=1,2, \cdots, n)
$$

In the formula $d_{t}=1 /(n-t+1)$, If $d^{2}$ is the second-order weakening buffer operator, then the

second-order buffer sequence of the actual value of ecological factor can be expressed as:

After the second-order buffer calculation of ecological factors, the data become more stable. In order to effectively evaluate the effect of ecological compensation, it is necessary to conduct dimensionless processing on the static data of ecological factors, and the value range of the data after processing is between $[0,1]$ (Yousefi and Ng, 2017). The dimensionless calculation formula is as follows:

$$
\begin{cases}X_{i t}^{\prime}=\left(X_{i t} d^{2}\right) /\left(\left(\max X_{i k}\right)\right) & (\text { forward pointer }) \\ X_{i t}^{\prime}=1-\left(X_{i t} d^{2}\right) /\left(\left(\max X_{i k}\right)\right) & (\text { contrary indicator })\end{cases}
$$

In the above equation $i=1,2, \cdots, m ; t=1,2, \cdots, n ; k=1,2, \cdots, 5: \mathrm{k}$ is the grading symbol in Table 3. $x_{i t}^{\prime}$ represents the dimensionless value of the $i_{\text {th }}$ evaluation factor in the $t$ year; $x_{i t}$ represents the original value of $i_{\text {th }}$ evaluation indicator in the $t$ year; $\max X_{i k}$ represents $i_{\text {th }}$ evaluation factor and the maximum value of $\mathrm{k}$, when the evaluation indicator is a positive indicator, the levellis the maximum value. When the evaluation indicator is a contrary indicator, the levelV is the maximum value. When the maximum value tends to infinity, the lower boundary value of the maximum interval is taken. When the positive indicator is larger than the lower boundary, the value range is 1 , and when the contrary indicator is larger than the lower boundary, the value range is zero. If the optimal suitability of the evaluation indicators is $x_{i \alpha}^{\prime}$, there are:

$$
X_{i \alpha}^{\prime}=\max \left(X_{i t}^{\prime}\right)
$$

On the basis of dimensionless processing, the null transformation is carried out according to the results of dimensionless processing. The absolute null transformation uses the following formula: 


$$
\left\{\begin{array}{l}
X_{i t}^{\prime}(0)=\left(X_{1 t}^{\prime}(0), X_{2 t}^{\prime}(0), \cdots, X_{m t}^{\prime}(0)\right)=X_{i t}-X_{1 t} \\
X_{i \alpha}^{\prime}(0)=\left(X_{1 \alpha}^{\prime}(0), X_{2 \alpha}^{\prime}(0), \cdots, X_{m \alpha}^{\prime}(0)\right)=X_{i \alpha}-X_{1 \alpha}
\end{array}\right.
$$

The comprehensive evaluation model of spatial niche suitability is the weighted average of the absolute niche suitability model and relative niche suitability model. In the actual construction of the evaluation model, the method and application of determining absolute and relative niche suitability model can be studied according to the specific requirements of the comprehensive evaluation. In order to construct a comprehensive evaluation model of spatial niche suitability, the absolute niche suitability measurement model is first constructed. The specific model expression is as follows:

$$
\begin{aligned}
& \varepsilon_{t \alpha}=\frac{1+\left|S_{\alpha}\right|+\left|S_{t}\right|}{1+\left|S_{\alpha}\right|+\left|S_{t}\right|+\left|S_{\alpha}-S_{t}\right|} \\
& \left\{\begin{array}{l}
S_{t}=\int_{1}^{m}\left(X_{i t}^{\prime}(0)-X_{i 1}^{\prime}(0)\right) d t \\
S_{\alpha}=\int_{1}^{m}\left(X_{i \alpha}^{\prime}(0)-X_{i 1}^{\prime \prime}(0)\right) d t \\
\left|S_{t}\right|=\left|\int_{1}^{m}\left(X_{i t}^{\prime}(0)-X_{i 1}^{\prime}(0)\right) d t\right|=\left|\sum_{i=2}^{m-1} X_{i t}^{\prime}(0)+\frac{1}{2} X_{m t}^{\prime}(0)\right| \\
\left|S_{\alpha}\right|=\left|\int_{1}^{m}\left(X_{i \alpha}^{\prime}(0)-X_{i 1}^{\prime}(0)\right) d t\right|=\left|\sum_{i=2}^{m-1} X_{i \alpha}^{\prime}(0)+\frac{1}{2} X_{m \alpha}^{\prime}(0)\right| \\
S_{\alpha}-S_{t}=\int_{1}^{m}\left(X_{i \alpha}^{\prime}(0)-X_{i t}^{\prime}(0)\right) d t \\
\left|S_{\alpha}-S_{t}\right|=\left|\sum_{i=2}^{m-1}\left(X_{i \alpha}^{\prime}(0)-X_{i t}^{\prime}(0)\right)+\frac{1}{2}\left(X_{m \alpha}^{\prime}(0)-X_{m t}^{\prime}(0)\right)\right|
\end{array}\right.
\end{aligned}
$$

Then, using the processing data after the second-order weakening buffer zone and the results of dimensionless processing, the relative niche suitability measurement model is constructed. The calculation formula of the relative null transformation for evaluation indicators is as follows:

$$
\left\{\begin{array}{l}
X_{i t}^{\prime}(0)=\left(X_{1 t}^{\prime}(0), X_{2 t}^{\prime}(0), \cdots, X_{m t}^{\prime}(0)\right)=\left(X_{i t} / X_{1 t}\right)-1 \\
X_{i \alpha}^{\prime}(0)=\left(X_{1 \alpha}^{\prime}(0), X_{2 \alpha}^{\prime}(0), \cdots, X_{m \alpha}^{\prime}(0)\right)=\left(X_{i \alpha} / X_{1 \alpha}\right)-1
\end{array}\right.
$$

In order to construct a comprehensive evaluation model of spatial niche suitability, a relative niche suitability measurement model needs to be constructed. The specific model of relative niche is as follows:

$$
\gamma_{t \alpha}=\frac{1+\left|S_{\alpha}^{\prime}\right|+\left|S_{t}^{\prime}\right|}{1+\left|S_{\alpha}^{\prime}\right|+\left|S_{t}^{\prime}\right|+\left|S_{\alpha}^{\prime}-S_{t}^{\prime}\right|}
$$




$$
\left\{\begin{array}{l}
S_{t}^{\prime}=\int_{1}^{m}\left(X_{i t}^{\prime \prime}(0)-X_{i 1}^{\prime \prime}(0)\right) d t \\
S_{\alpha}^{\prime}=\int_{1}^{m}\left(X_{i \alpha}^{\prime \prime}(0)-X_{i 1}^{\prime \prime}(0)\right) d t \\
\left|S_{t}^{\prime}\right|=\left|\int_{1}^{m}\left(X_{i t}^{\prime \prime}(0)-X_{i 1}^{\prime \prime}(0)\right) d t\right|=\left|\sum_{i=2}^{m-1} X_{i t}^{\prime \prime}(0)+\frac{1}{2} X_{m t}^{\prime \prime}(0)\right| \\
\left|S_{\alpha}^{\prime}\right|=\left|\int_{1}^{m}\left(X_{i \alpha}^{\prime \prime}(0)-X_{i 1}^{\prime \prime}(0)\right) d t\right|=\left|\sum_{i=2}^{m-1} X_{i \alpha}^{\prime \prime}(0)+\frac{1}{2} X_{m \alpha}^{\prime \prime}(0)\right| \\
S_{\alpha}^{\prime}-S_{t}^{\prime}=\int_{1}^{m}\left(X_{i \alpha}^{\prime \prime}(0)-X_{i t}^{\prime \prime}(0)\right) d t \\
\left|S_{\alpha}^{\prime}-S_{t}^{\prime}\right|=\left|\sum_{i=2}^{m-1}\left(X_{i \alpha}^{\prime \prime}(0)-X_{i t}^{\prime \prime}(0)\right)+\frac{1}{2}\left(X_{m \alpha}^{\prime \prime}(0)-X_{m t}^{\prime \prime}(0)\right)\right|
\end{array}\right.
$$

In the above formula, if $F_{t \alpha}$ is used to represent the comprehensive evaluation model of spatial niche suitability, there are:

$$
F_{t \alpha}=\theta \varepsilon_{t \alpha}+(1-\theta) \gamma_{t \alpha}
$$

Where, $\theta(0 \leq \theta \leq 1)$ is the weighting coefficient, and considering that the importance of the absolute niche suitability and the relative niche suitability are the same, the value of $\theta$ is taken as 0.5 .

When the value of $\theta$ is less than 0.5 and tends to 0 , the value of spatial niche suitability tends to relative niche suitability. When the value of $\theta$ is greater than 0.5 and tends to 1 , the value of spatial niche suitability tends to absolute niche suitability.

\section{Result}

\subsection{Second-order buffer calculation of evaluation indicators}

The purpose of buffer calculation is to improve the stability of the evaluation indicators. For the basic data in Table 1, the second-order buffer correction formulas (5) and (6) of evaluation indicators were used for buffer calculation to eliminate the large fluctuation in the original data, which can make the data more stable and improve the effectiveness of the comprehensive evaluation results of the ecological compensation for environmental pollution loss in Nanjing MV Industrial Park. According to the above research design, the second-order buffer calculation is carried out for the comprehensive evaluation indicators by using the buffer calculation model, and the specific buffer calculation results are shown in Table 4. 


\begin{tabular}{|c|c|c|c|c|c|c|c|c|}
\hline Indicators & 2011 & 2012 & 2013 & 2014 & 2015 & 2016 & 2017 & 2018 \\
\hline $\mathrm{X}_{11}$ & 14.1287 & 14.3646 & 14.6287 & 14.9247 & 15.2556 & 15.6108 & 15.9867 & 16.3217 \\
\hline$X_{12}$ & 25.0141 & 25.3340 & 25.6913 & 26.1279 & 26.7254 & 27.4439 & 27.8475 & 28.3700 \\
\hline$X_{13}$ & 0.6181 & 0.6026 & 0.5865 & 0.5705 & 0.5557 & 0.5388 & 0.5192 & 0.4981 \\
\hline $\mathrm{X}_{14}$ & 48.0911 & 48.1525 & 48.2110 & 48.2648 & 48.3010 & 48.2989 & 48.1850 & 48.0600 \\
\hline $\mathrm{X}_{15}$ & 434.0152 & 437.1245 & 440.3833 & 443.3933 & 446.0417 & 447.5556 & 449.0000 & 450.0000 \\
\hline $\mathrm{X}_{16}$ & 1.8581 & 1.8733 & 1.8893 & 1.9076 & 1.9292 & 1.9512 & 1.9835 & 2.0137 \\
\hline $\mathrm{X}_{21}$ & 159.5095 & 162.8284 & 166.1845 & 169.4181 & 172.3656 & 175.1550 & 177.0975 & 176.6700 \\
\hline $\mathrm{X}_{22}$ & 27.6976 & 27.9350 & 28.1977 & 28.4963 & 28.8533 & 29.2911 & 29.7900 & 30.2800 \\
\hline $\mathrm{X}_{23}$ & 94.4851 & 94.6237 & 94.7621 & 94.8992 & 95.0335 & 95.1589 & 95.2450 & 95.1200 \\
\hline $\mathrm{X}_{24}$ & 87.0457 & 87.6769 & 88.3412 & 89.0244 & 89.7175 & 90.3750 & 90.7625 & 91.2600 \\
\hline $\mathrm{X}_{25}$ & 89.4786 & 89.5906 & 89.7026 & 89.8148 & 89.9290 & 90.0594 & 90.2125 & 90.3200 \\
\hline $\mathrm{X}_{26}$ & 96.9273 & 97.0408 & 97.1426 & 97.2291 & 97.3069 & 97.3567 & 97.2900 & 97.2800 \\
\hline $\mathrm{X}_{31}$ & 73.5132 & 73.9810 & 74.5083 & 75.1090 & 75.8727 & 76.9144 & 78.2600 & 80.3200 \\
\hline$X_{32}$ & 1.4864 & 1.4504 & 1.4111 & 1.3683 & 1.3209 & 1.2641 & 1.1941 & 1.0827 \\
\hline $\mathrm{X}_{33}$ & 0.3313 & 0.3234 & 0.3160 & 0.3094 & 0.3036 & 0.2992 & 0.2980 & 0.3026 \\
\hline $\mathrm{X}_{34}$ & 0.7768 & 0.7462 & 0.7124 & 0.6739 & 0.6305 & 0.5814 & 0.5325 & 0.4825 \\
\hline $\mathrm{X}_{35}$ & 104.6237 & 96.2403 & 87.9184 & 79.6704 & 71.3585 & 63.4056 & 56.7250 & 49.5400 \\
\hline $\mathrm{X}_{36}$ & 82.6737 & 77.1330 & 71.9342 & 67.1210 & 62.6198 & 58.0472 & 54.0775 & 50.3200 \\
\hline $\mathrm{X}_{37}$ & 54.1511 & 52.2155 & 50.6510 & 49.6832 & 49.1215 & 48.8061 & 48.5625 & 48.3200 \\
\hline $\mathrm{X}_{38}$ & 102.5376 & 95.2756 & 87.9871 & 80.5291 & 72.9929 & 66.0639 & 61.2875 & 58.2900 \\
\hline $\mathrm{X}_{41}$ & 78.7649 & 79.4458 & 80.1698 & 80.9591 & 81.8454 & 82.9039 & 84.3075 & 86.2800 \\
\hline $\mathrm{X}_{42}$ & 78.7736 & 79.0515 & 79.2660 & 79.4502 & 79.6238 & 79.8800 & 80.1300 & 80.3800 \\
\hline $\mathrm{X}_{43}$ & 81.1058 & 81.6000 & 82.0717 & 82.5227 & 82.9494 & 83.3667 & 83.8150 & 84.2900 \\
\hline $\mathrm{X}_{44}$ & 84.5518 & 85.4603 & 86.4382 & 87.4669 & 88.5096 & 89.5878 & 90.5950 & 91.0200 \\
\hline $\mathrm{X}_{45}$ & 88.8509 & 89.3848 & 89.8625 & 90.2930 & 90.6727 & 91.0144 & 91.3200 & 91.6700 \\
\hline $\mathrm{X}_{46}$ & 144.6155 & 149.2716 & 153.8803 & 158.0063 & 161.4719 & 163.2750 & 164.4075 & 165.4700 \\
\hline
\end{tabular}

3.2 Dimensionless processing of evaluation indicators

Dimensionless refers to the behavior or process of removing part or all of the dimensionality of the

318 physical quantity of the comprehensive evaluation indicators by selecting appropriate variables instead.

319 The most commonly used dimensionless treatment is normalization, to merge all the values of the

320 evaluation indicators into $[0,1]$ by specific methods. For the difference between the positive pointers and the

321 contrary indicators, the merging principle of the positive pointers is the maximum of 1 and the minimum of

3220 ; the merging principle of the contrary indicators is the opposite of the positive pointers, the minimum of 1 
Table 5 Dimensionless processing results of the ECEE indicators of energy consumption pollution treatment in Nanjing MV Industrial Park

\begin{tabular}{|c|c|c|c|c|c|c|c|c|c|}
\hline Indicators & 2011 & 2012 & 2013 & 2014 & 2015 & 2016 & 2017 & 2018 & $x_{i \alpha}^{\prime}$ \\
\hline $\mathrm{X}_{11}$ & 0.8311 & 0.8450 & 0.8605 & 0.8779 & 0.8974 & 0.9183 & 0.9404 & 0.9601 & 0.8311 \\
\hline $\mathrm{X}_{12}$ & 0.8338 & 0.8445 & 0.8564 & 0.8709 & 0.8908 & 0.9148 & 0.9283 & 0.9457 & 0.8338 \\
\hline $\mathrm{X}_{13}$ & 0.6909 & 0.6987 & 0.7067 & 0.7148 & 0.7222 & 0.7306 & 0.7404 & 0.7510 & 0.6909 \\
\hline $\mathrm{X}_{14}$ & 0.9618 & 0.9630 & 0.9642 & 0.9653 & 0.9660 & 0.9660 & 0.9637 & 0.9612 & 0.9618 \\
\hline $\mathrm{X}_{15}$ & 0.8680 & 0.8742 & 0.8808 & 0.8868 & 0.8921 & 0.8951 & 0.8980 & 0.9000 & 0.8680 \\
\hline $\mathrm{X}_{16}$ & 0.7432 & 0.7493 & 0.7557 & 0.7630 & 0.7717 & 0.7805 & 0.7934 & 0.8055 & 0.7432 \\
\hline $\mathrm{X}_{21}$ & 0.7975 & 0.8141 & 0.8309 & 0.8471 & 0.8618 & 0.8758 & 0.8855 & 0.8834 & 0.7975 \\
\hline $\mathrm{X}_{22}$ & 0.8656 & 0.8730 & 0.8812 & 0.8905 & 0.9017 & 0.9153 & 0.9309 & 0.9463 & 0.8656 \\
\hline $\mathrm{X}_{23}$ & 0.9449 & 0.9462 & 0.9476 & 0.9490 & 0.9503 & 0.9516 & 0.9525 & 0.9512 & 0.9449 \\
\hline $\mathrm{X}_{24}$ & 0.4352 & 0.4384 & 0.4417 & 0.4451 & 0.4486 & 0.4519 & 0.4538 & 0.4563 & 0.4352 \\
\hline $\mathrm{X}_{25}$ & 0.8948 & 0.8959 & 0.8970 & 0.8981 & 0.8993 & 0.9006 & 0.9021 & 0.9032 & 0.8948 \\
\hline $\mathrm{X}_{26}$ & 0.9693 & 0.9704 & 0.9714 & 0.9723 & 0.9731 & 0.9736 & 0.9729 & 0.9728 & 0.9693 \\
\hline $\mathrm{X}_{31}$ & 0.7351 & 0.7398 & 0.7451 & 0.7511 & 0.7587 & 0.7691 & 0.7826 & 0.8032 & 0.7351 \\
\hline $\mathrm{X}_{32}$ & 0.4054 & 0.4198 & 0.4356 & 0.4527 & 0.4716 & 0.4944 & 0.5224 & 0.5669 & 0.4054 \\
\hline $\mathrm{X}_{33}$ & 0.6687 & 0.6766 & 0.6840 & 0.6906 & 0.6964 & 0.7008 & 0.7020 & 0.6974 & 0.6687 \\
\hline $\mathrm{X}_{34}$ & 0.6116 & 0.6269 & 0.6438 & 0.6631 & 0.6848 & 0.7093 & 0.7337 & 0.7588 & 0.6116 \\
\hline $\mathrm{X}_{35}$ & 0.7908 & 0.8075 & 0.8242 & 0.8407 & 0.8573 & 0.8732 & 0.8866 & 0.9009 & 0.7908 \\
\hline $\mathrm{X}_{36}$ & 0.7244 & 0.7429 & 0.7602 & 0.7763 & 0.7913 & 0.8065 & 0.8197 & 0.8323 & 0.7244 \\
\hline $\mathrm{X}_{37}$ & 0.8195 & 0.8259 & 0.8312 & 0.8344 & 0.8363 & 0.8373 & 0.8381 & 0.8389 & 0.8195 \\
\hline $\mathrm{X}_{38}$ & 0.6582 & 0.6824 & 0.7067 & 0.7316 & 0.7567 & 0.7798 & 0.7957 & 0.8057 & 0.6582 \\
\hline $\mathrm{X}_{41}$ & 0.7876 & 0.7945 & 0.8017 & 0.8096 & 0.8185 & 0.8290 & 0.8431 & 0.8628 & 0.7876 \\
\hline $\mathrm{X}_{42}$ & 0.7877 & 0.7905 & 0.7927 & 0.7945 & 0.7962 & 0.7988 & 0.8013 & 0.8038 & 0.7877 \\
\hline $\mathrm{X}_{43}$ & 0.8111 & 0.8160 & 0.8207 & 0.8252 & 0.8295 & 0.8337 & 0.8382 & 0.8429 & 0.8111 \\
\hline $\mathrm{X}_{44}$ & 0.8455 & 0.8546 & 0.8644 & 0.8747 & 0.8851 & 0.8959 & 0.9060 & 0.9102 & 0.8455 \\
\hline $\mathrm{X}_{45}$ & 0.8885 & 0.8938 & 0.8986 & 0.9029 & 0.9067 & 0.9101 & 0.9132 & 0.9167 & 0.8885 \\
\hline $\mathrm{X}_{46}$ & 0.7231 & 0.7464 & 0.7694 & 0.7900 & 0.8074 & 0.8164 & 0.8220 & 0.8274 & 0.7231 \\
\hline
\end{tabular}

In order to improve the evaluation effect, the dimensionless maximum value is selected according to

330 the maximum value in Table 3 . The lower boundary value is selected when the maximum value tends to

331 infinity; the value range of the positive pointer greater than such standard is 1 , and the value range of the

332 contrary indicator greater than such standard is 0 . 
(1) Absolute null transformation calculation. Absolute null transformation processing refers to the use

of the difference method to determine the zero base of the first row, that is, the data of each row of all

evaluation indicators minus the base data of the first row, so that the difference of the first row is zero, and

the calculation of correlation coefficient is started from zero, and the method of generalized relational grade

objects. The specific calculation results are shown in Table 6 .

Table 6 The results of absolute null transformation for the ECEE indicators of energy consumption pollution treatment in Nanjing MV Industrial Park

\begin{tabular}{|c|c|c|c|c|c|c|c|c|c|}
\hline Indicators & 2011 & 2012 & 2013 & 2014 & 2015 & 2016 & 2017 & 2018 & $x_{i \alpha}^{\prime}(0)$ \\
\hline $\mathrm{X}_{11}$ & 0 & 0 & 0 & 0 & 0 & 0 & 0 & 0 & 0 \\
\hline $\mathrm{X}_{12}$ & 0.0027 & -0.0005 & -0.0041 & -0.0070 & -0.0065 & -0.0035 & -0.0121 & -0.0144 & -0.0144 \\
\hline $\mathrm{X}_{13}$ & -0.1401 & -0.1463 & -0.1538 & -0.1632 & -0.1752 & -0.1877 & -0.2000 & -0.2092 & -0.2092 \\
\hline $\mathrm{X}_{14}$ & 0.1307 & 0.1181 & 0.1037 & 0.0874 & 0.0686 & 0.0477 & 0.0233 & 0.0011 & 0.0059 \\
\hline $\mathrm{X}_{15}$ & 0.0369 & 0.0293 & 0.0203 & 0.0089 & -0.0053 & -0.0232 & -0.0424 & -0.0601 & -0.0601 \\
\hline $\mathrm{X}_{16}$ & -0.0879 & -0.0957 & -0.1048 & -0.1149 & -0.1257 & -0.1378 & -0.1470 & -0.1546 & -0.1546 \\
\hline $\mathrm{X}_{21}$ & -0.0335 & -0.0308 & -0.0296 & -0.0308 & -0.0356 & -0.0425 & -0.0549 & -0.0768 & -0.0746 \\
\hline $\mathrm{X}_{22}$ & 0.0345 & 0.0280 & 0.0207 & 0.0126 & 0.0043 & -0.0029 & -0.0095 & -0.0138 & -0.0138 \\
\hline$X_{23}$ & 0.1138 & 0.1013 & 0.0871 & 0.0711 & 0.0529 & 0.0333 & 0.0121 & -0.0089 & -0.0076 \\
\hline $\mathrm{X}_{24}$ & -0.3959 & -0.4066 & -0.4188 & -0.4328 & -0.4488 & -0.4664 & -0.4866 & -0.5038 & -0.5038 \\
\hline $\mathrm{X}_{25}$ & 0.0637 & 0.0509 & 0.0365 & 0.0202 & 0.0019 & -0.0177 & -0.0383 & -0.0569 & -0.0569 \\
\hline $\mathrm{X}_{31}$ & 0.1382 & 0.1254 & 0.1109 & 0.0944 & 0.0757 & 0.0553 & 0.0325 & 0.0127 & 0.0135 \\
\hline$X_{32}$ & -0.0960 & -0.1052 & -0.1154 & -0.1268 & -0.1387 & -0.1491 & -0.1578 & -0.1569 & -0.1569 \\
\hline $\mathrm{X}_{33}$ & -0.4257 & -0.4252 & -0.4250 & -0.4252 & -0.4258 & -0.4239 & -0.4180 & -0.3932 & -0.3932 \\
\hline $\mathrm{X}_{34}$ & -0.1624 & -0.1684 & -0.1765 & -0.1874 & -0.2010 & -0.2175 & -0.2384 & -0.2627 & -0.2581 \\
\hline $\mathrm{X}_{35}$ & -0.2195 & -0.2181 & -0.2167 & -0.2149 & -0.2126 & -0.2090 & -0.2067 & -0.2014 & -0.2014 \\
\hline $\mathrm{X}_{41}$ & -0.0403 & -0.0375 & -0.0363 & -0.0373 & -0.0401 & -0.0451 & -0.0538 & -0.0592 & -0.0592 \\
\hline $\mathrm{X}_{42}$ & -0.1067 & -0.1021 & -0.1003 & -0.1017 & -0.1061 & -0.1118 & -0.1207 & -0.1278 & -0.1278 \\
\hline $\mathrm{X}_{43}$ & -0.0116 & -0.0190 & -0.0293 & -0.0435 & -0.0611 & -0.0810 & -0.1023 & -0.1212 & -0.1212 \\
\hline $\mathrm{X}_{44}$ & -0.1729 & -0.1626 & -0.1538 & -0.1464 & -0.1407 & -0.1385 & -0.1447 & -0.1544 & -0.1544 \\
\hline $\mathrm{X}_{51}$ & -0.0434 & -0.0505 & -0.0588 & -0.0683 & -0.0789 & -0.0892 & -0.0973 & -0.0973 & -0.0973 \\
\hline $\mathrm{X}_{52}$ & -0.0434 & -0.0545 & -0.0679 & -0.0834 & -0.1011 & -0.1195 & -0.1391 & -0.1563 & -0.1563 \\
\hline $\mathrm{X}_{53}$ & -0.0200 & -0.0290 & -0.0398 & -0.0527 & -0.0679 & -0.0846 & -0.1022 & -0.1172 & -0.1172 \\
\hline $\mathrm{X}_{54}$ & 0.0144 & 0.0096 & 0.0039 & -0.0033 & -0.0123 & -0.0224 & -0.0344 & -0.0499 & -0.0499 \\
\hline $\mathrm{X}_{55}$ & 0.0574 & 0.0489 & 0.0381 & 0.0250 & 0.0093 & -0.0081 & -0.0272 & -0.0434 & -0.0434 \\
\hline $\mathrm{X}_{56}$ & -0.1080 & -0.0986 & -0.0911 & -0.0879 & -0.0900 & -0.1019 & -0.1184 & -0.1328 & -0.1328 \\
\hline
\end{tabular}

(2) Relative null transformation calculation. Relative null transformation processing refers to the use

of the ratio method to determine the zero base of the first row, that is, the ratio of the data in each row of 
344 data in the first row is zero. The specific calculation results are shown in Table 7.

345 Table 7 The results of relative null transformation for the ECEE indicators of energy consumption pollution treatment in Nanjing MV Industrial Park

\begin{tabular}{|c|c|c|c|c|c|c|c|c|c|}
\hline Indicators & 2011 & 2012 & 2013 & 2014 & 2015 & 2016 & 2017 & 2018 & $x_{i \alpha}^{\prime \prime}(0)$ \\
\hline $\mathrm{X}_{11}$ & 0 & 0 & 0 & 0 & 0 & 0 & 0 & 0 & 0 \\
\hline $\mathrm{X}_{12}$ & 0.0033 & -0.0006 & -0.0048 & -0.0080 & -0.0073 & -0.0038 & -0.0129 & -0.0150 & -0.0150 \\
\hline $\mathrm{X}_{13}$ & -0.1686 & -0.1731 & -0.1787 & -0.1858 & -0.1953 & -0.2044 & -0.2127 & -0.2178 & -0.2178 \\
\hline $\mathrm{X}_{14}$ & 0.1573 & 0.1397 & 0.1205 & 0.0995 & 0.0765 & 0.0519 & 0.0248 & 0.0011 & 0.0062 \\
\hline $\mathrm{X}_{15}$ & 0.0444 & 0.0346 & 0.0235 & 0.0101 & -0.0059 & -0.0252 & -0.0451 & -0.0626 & -0.0626 \\
\hline $\mathrm{X}_{16}$ & -0.1057 & -0.1132 & -0.1218 & -0.1309 & -0.1401 & -0.1501 & -0.1563 & -0.1610 & -0.1610 \\
\hline $\mathrm{X}_{21}$ & -0.0404 & -0.0365 & -0.0344 & -0.0351 & -0.0396 & -0.0463 & -0.0584 & -0.0799 & -0.0777 \\
\hline $\mathrm{X}_{22}$ & 0.0415 & 0.0331 & 0.0240 & 0.0143 & 0.0048 & -0.0032 & -0.0101 & -0.0144 & -0.0144 \\
\hline $\mathrm{X}_{23}$ & 0.1369 & 0.1198 & 0.1012 & 0.0809 & 0.0590 & 0.0363 & 0.0128 & -0.0093 & -0.0080 \\
\hline $\mathrm{X}_{24}$ & -0.4763 & -0.4812 & -0.4867 & -0.4930 & -0.5001 & -0.5079 & -0.5174 & -0.5247 & -0.5247 \\
\hline $\mathrm{X}_{25}$ & 0.0766 & 0.0603 & 0.0424 & 0.0230 & 0.0021 & -0.0193 & -0.0407 & -0.0593 & -0.0593 \\
\hline $\mathrm{X}_{31}$ & 0.1663 & 0.1484 & 0.1289 & 0.1075 & 0.0843 & 0.0602 & 0.0346 & 0.0132 & 0.0140 \\
\hline$X_{32}$ & -0.1155 & -0.1245 & -0.1341 & -0.1445 & -0.1545 & -0.1624 & -0.1678 & -0.1634 & -0.1634 \\
\hline $\mathrm{X}_{33}$ & -0.5122 & -0.5032 & -0.4938 & -0.4844 & -0.4744 & -0.4616 & -0.4445 & -0.4095 & -0.4095 \\
\hline $\mathrm{X}_{34}$ & -0.1954 & -0.1993 & -0.2052 & -0.2134 & -0.2240 & -0.2369 & -0.2535 & -0.2736 & -0.2689 \\
\hline $\mathrm{X}_{35}$ & -0.2641 & -0.2581 & -0.2518 & -0.2447 & -0.2369 & -0.2276 & -0.2198 & -0.2097 & -0.2097 \\
\hline $\mathrm{X}_{41}$ & -0.0485 & -0.0443 & -0.0422 & -0.0424 & -0.0447 & -0.0491 & -0.0573 & -0.0616 & -0.0616 \\
\hline $\mathrm{X}_{42}$ & -0.1284 & -0.1208 & -0.1165 & -0.1158 & -0.1183 & -0.1217 & -0.1283 & -0.1331 & -0.1331 \\
\hline$X_{43}$ & -0.0140 & -0.0225 & -0.0341 & -0.0496 & -0.0681 & -0.0882 & -0.1087 & -0.1262 & -0.1262 \\
\hline $\mathrm{X}_{44}$ & -0.2080 & -0.1924 & -0.1787 & -0.1667 & -0.1568 & -0.1508 & -0.1539 & -0.1608 & -0.1608 \\
\hline $\mathrm{X}_{51}$ & -0.0523 & -0.0598 & -0.0683 & -0.0778 & -0.0880 & -0.0972 & -0.1035 & -0.1013 & -0.1013 \\
\hline $\mathrm{X}_{52}$ & -0.0522 & -0.0645 & -0.0788 & -0.0950 & -0.1127 & -0.1301 & -0.1479 & -0.1628 & -0.1628 \\
\hline $\mathrm{X}_{53}$ & -0.0241 & -0.0343 & -0.0462 & -0.0600 & -0.0757 & -0.0921 & -0.1087 & -0.1221 & -0.1221 \\
\hline $\mathrm{X}_{54}$ & 0.0174 & 0.0114 & 0.0045 & -0.0037 & -0.0137 & -0.0244 & -0.0366 & -0.0520 & -0.0520 \\
\hline $\mathrm{X}_{55}$ & 0.0691 & 0.0578 & 0.0443 & 0.0285 & 0.0104 & -0.0089 & -0.0289 & -0.0452 & -0.0452 \\
\hline $\mathrm{X}_{56}$ & -0.1300 & -0.1167 & -0.1059 & -0.1001 & -0.1003 & -0.1110 & -0.1259 & -0.1383 & -0.1383 \\
\hline
\end{tabular}

\subsection{Evaluation results of ecological compensation effect of environmental pollution loss}


model, the selected 26 evaluation indicators were comprehensively evaluated to determine the treatment in Nanjing MV Industrial Park. See Table 8 for details.

Table 8 The results of ECEE of environmental pollution treatment of Nanjing MV Industrial Park for the target layer indicators

\begin{tabular}{|c|c|c|c|c|c|c|c|c|c|}
\hline Evaluation method & Indicators & 2011 & 2012 & 2013 & 2014 & 2015 & 2016 & 2017 & 2018 \\
\hline \multirow{6}{*}{$\varepsilon_{t \alpha}$} & $\left|S_{t}\right|$ & 0.4483 & 0.6205 & 0.8437 & 1.1242 & 1.4613 & 1.8311 & 2.2675 & 2.6181 \\
\hline & $\left|S_{\alpha}-S_{t}\right|$ & 1.4417 & 1.3320 & 1.1874 & 1.0025 & 0.7773 & 0.5254 & 0.2268 & 0.0136 \\
\hline & $1+\left|S_{\alpha}\right|+\left|S_{t}\right|$ & 3.4461 & 3.7183 & 4.4414 & 4.7220 & 5.0590 & 5.4288 & 5.8652 & 6.1358 \\
\hline & $1+\left|S_{\alpha}\right|+\left|S_{t}\right|+\left|S_{\alpha}-S_{t}\right|$ & 4.8878 & 5.0503 & 5.7689 & 5.8645 & 5.8863 & 5.9862 & 6.2320 & 6.2694 \\
\hline & Evaluation results & 0.7050 & 0.7363 & 0.7699 & 0.8052 & 0.8595 & 0.9069 & 0.9411 & 0.9787 \\
\hline & Level & III & III & III & II & II & I & I & I \\
\hline \multirow{6}{*}{$\gamma_{t \alpha}$} & $\left|S_{t}\right|$ & 2.5977 & 0.5712 & 0.7776 & 1.0381 & 1.3559 & 1.7242 & 2.1113 & 2.5530 \\
\hline & $\left|S_{\alpha}^{\prime}-S_{t}^{\prime}\right|$ & 1.5335 & 1.4029 & 1.2350 & 1.0262 & 0.7806 & 0.5168 & 0.2145 & 0.0149 \\
\hline & $1+\left|S_{\alpha}^{\prime}\right|+\left|S_{t}^{\prime}\right|$ & 4.6360 & 4.6424 & 4.9030 & 5.2208 & 5.5890 & 5.9762 & 6.1879 & 6.7521 \\
\hline & $1+\left|S_{\alpha}^{\prime}\right|+\left|S_{t}^{\prime}\right|+\left|S_{\alpha}^{\prime}-S_{t}^{\prime}\right|$ & 6.0196 & 5.8697 & 6.0178 & 6.1669 & 6.2696 & 6.3893 & 6.4023 & 6.7671 \\
\hline & Evaluation results & 0.7702 & 0.7909 & 0.8147 & 0.8466 & 0.8914 & 0.9353 & 0.9665 & 0.9978 \\
\hline & Level & III & III & II & II & II & I & I & I \\
\hline \multirow{5}{*}{$F_{t \alpha}$} & $\varepsilon_{t \alpha}$ & 0.7050 & 0.7363 & 0.7699 & 0.8052 & 0.8595 & 0.9069 & 0.9411 & 0.9787 \\
\hline & $\gamma_{t \alpha}$ & 0.7702 & 0.7909 & 0.8147 & 0.8466 & 0.8914 & 0.9353 & 0.9665 & 0.9978 \\
\hline & $\theta$ & 0.5 & 0.5 & 0.5 & 0.5 & 0.5 & 0.5 & 0.5 & 0.5 \\
\hline & Evaluation results & 0.7376 & 0.7636 & 0.7923 & 0.8259 & 0.8755 & 0.9211 & 0.9538 & 0.9883 \\
\hline & Level & III & III & III & II & II & I & I & I \\
\hline
\end{tabular}

(2) Comprehensive evaluation result of criterion layer indicators. If the criterion layer indicators are used as the evaluation objects, the basic data of the measures layer indicators contained in each indicator of the criterion layer and formulas $(9) \sim(12)$ can be used to comprehensively evaluate the criterion layer indicators. The evaluation results of the three methods are shown in Table 9. 


\begin{tabular}{c|c|c|c|c|c|c|c|c|c}
\hline Evaluation method & Indicators & 2011 & 2012 & 2013 & 2014 & 2015 & 2016 & 2017 & 2018 \\
\hline \multirow{4}{*}{$\varepsilon_{t \alpha}$} & $\mathrm{X}_{1}$ & 0.7052 & 0.7365 & 0.7701 & 0.8054 & 0.8597 & 0.9071 & 0.9413 & 0.9789 \\
\cline { 2 - 10 } & $\mathrm{X}_{2}$ & 0.7105 & 0.7420 & 0.7759 & 0.8114 & 0.8662 & 0.9139 & 0.9484 & 0.9863 \\
\cline { 2 - 10 } & $\mathrm{X}_{3}$ & 0.6725 & 0.7076 & 0.7399 & 0.7738 & 0.8260 & 0.8716 & 0.9044 & 0.9406 \\
\cline { 2 - 10 } & $\mathrm{X}_{4}$ & 0.6820 & 0.7227 & 0.7557 & 0.7903 & 0.8436 & 0.8901 & 0.9237 & 0.9606 \\
\hline \multirow{5}{*}{$\gamma_{t \alpha}$} & $\mathrm{X}_{1}$ & 0.7612 & 0.7829 & 0.8052 & 0.8364 & 0.8861 & 0.9278 & 0.9627 & 0.9957 \\
\cline { 2 - 10 } & $\mathrm{X}_{2}$ & 0.7726 & 0.7932 & 0.8206 & 0.8466 & 0.8975 & 0.9386 & 0.9703 & 0.9968 \\
\cline { 2 - 10 } & $\mathrm{X}_{3}$ & 0.7243 & 0.7436 & 0.7883 & 0.8167 & 0.8467 & 0.8977 & 0.9181 & 0.9565 \\
\hline \multirow{5}{*}{$F_{t \alpha}$} & $\mathrm{X}_{4}$ & 0.7747 & 0.7946 & 0.8207 & 0.8508 & 0.9016 & 0.9438 & 0.9974 & 0.9986 \\
\cline { 2 - 10 } & $\mathrm{X}_{1}$ & 0.7332 & 0.7597 & 0.7877 & 0.8209 & 0.8729 & 0.9175 & 0.9520 & 0.9873 \\
\hline & $\mathrm{X}_{2}$ & 0.7416 & 0.7676 & 0.7983 & 0.8290 & 0.8819 & 0.9263 & 0.9594 & 0.9916 \\
\cline { 2 - 10 } & $\mathrm{X}_{3}$ & 0.6984 & 0.7256 & 0.7641 & 0.7953 & 0.8364 & 0.8847 & 0.9113 & 0.9486 \\
\hline
\end{tabular}

\section{Discussion}

\subsection{Evaluation grade change rule and problems found}

In order to analyze the laws and problems of the evaluation results, effective improvement strategies are formulated according to the analysis results. In the rectangular coordinate system, draw the change rule diagram of the evaluation result of the ecological compensation effect of the environmental pollution

loss at the criterion layer. The specific change rule and the interrelation are shown in Figure 1.

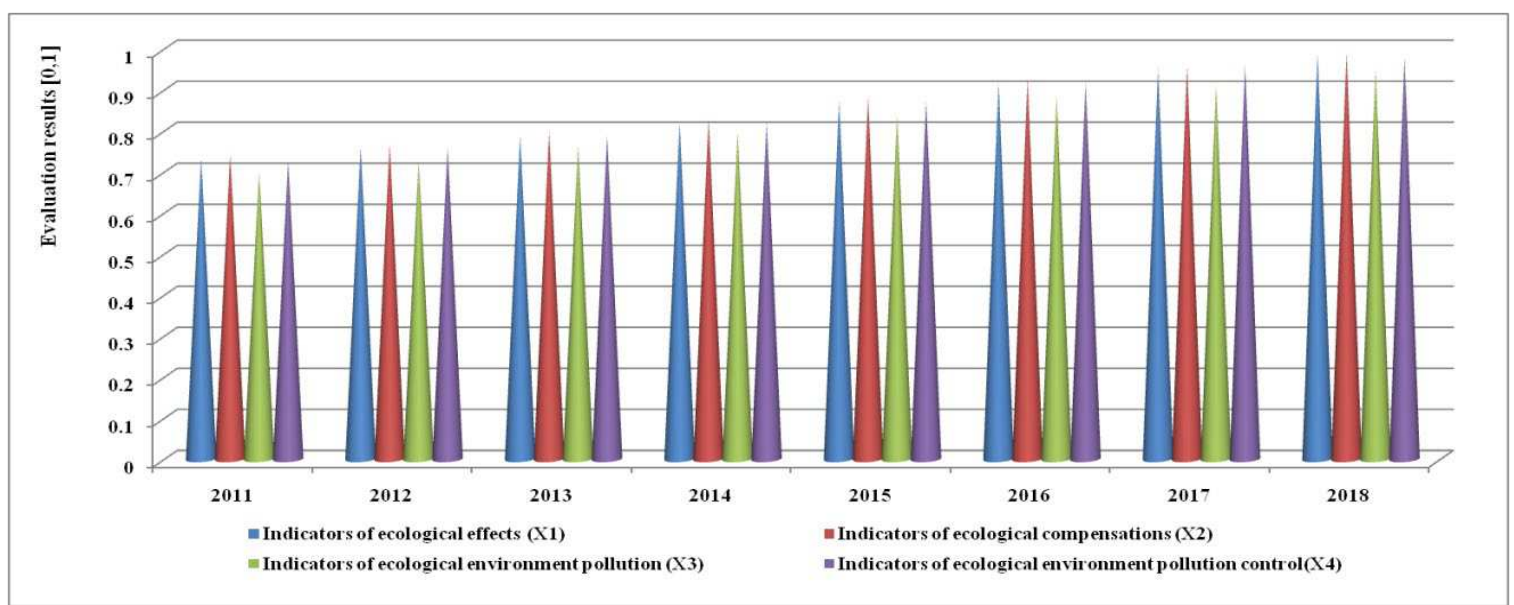

Fig.1. Change rule and interrelation diagram of the results of ECEE of environmental pollution loss in Nanjing MV Industrial Park

According to the evaluation results of the ecological compensation effect of environmental pollution 
loss in Nanjing MV Industrial Park for criteria layer, the evaluation result of the ecological compensation effect for the economic effect indicators in 2011 was 0.7332 (level III), which was a medium level. By 2018, the evaluation result of the ecological compensation effect was increased to 0.9873 (level I), which was the excellent level; the evaluation result of the ecological compensation effect for the ecological compensation indicators in 2011 is 0.7416 (Level III), which was the medium level. By 2018, it increased to 0.9916 (Level I), which was the excellent level; the evaluation result of the ecological compensation effect for the ecological environmental pollution indicators in 2011 was 0.6984 (Level IV), which was the qualified level. By 2018, it increased to 0.9484 (level I), which was the excellent level; the evaluation result of the ecological compensation effect for the ecological environmental pollution treatment indicators in 2011 was 0.7284 (Level III), which was the medium level. By 2018, it increased to 0.9796 (level I), which was the excellent level.

From the above evaluation results, it can be seen that the ecological compensation effect of environmental pollution in Nanjing MV Industrial Park is good, indicating that the economic development of the industrial park is good, and more attention is paid to environmental pollution treatment. However, the status of ecological compensation and environmental pollution in the industrial park is still not ideal, in particular, the evaluation results in 2011-2013 ware level III, the evaluation results for 2014-2015 ware level II, and although they were level I for 2016-2018, the evaluation results of the first two years were obviously low. Improving the effectiveness of environmental pollution treatment is still the main issue faced by Nanjing MV Industrial Park, which needs to be further strengthened.

\subsection{The implementation effect of ecological compensation system and the problems found}

Nanjing MV Industrial Park has implemented a comprehensive ecological compensation system for environmental pollution losses since 2018. According to the collected data, the influencing factor diagram 

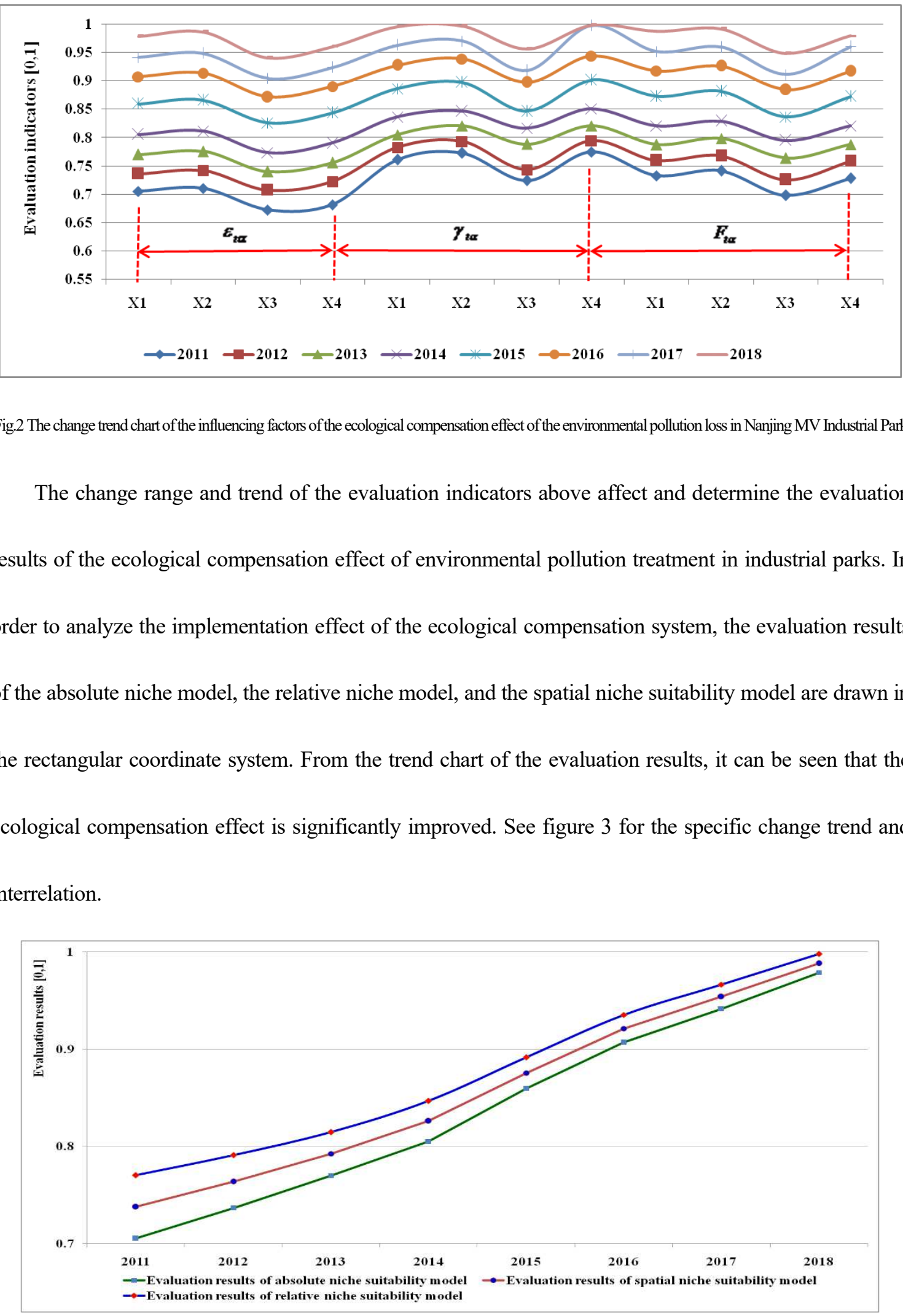

compensation effect of Nanjing MV Industrial Park in 2018 and the previous year's evaluation results, it can be seen that the ecological compensation effect in 2018 is significantly improved compared with any year before 2018, indicating that the ecological compensation effect of the environmental pollution loss in

410 Nanjing MV Industrial Park has had an obvious effect since 2018. Although it can't be said that these obvious effects are all brought by the implementation of the ecological compensation scheme, it is certain that there will be effects brought by the implementation of the ecological compensation scheme. The ecological compensation for environmental pollution loss in Nanjing MV Industrial Park is a long-term task. It needs a long-term process to verify the effectiveness of the implementation of the ecological compensation scheme for environmental pollution loss. With the continuous implementation of the ecological compensation scheme for environmental pollution loss in Nanjing MV Industrial Park, its continuous research and exploration, the Nanjing MV Industrial Park can gradually improve the ecological

\section{Conclusions}

In order to solve the comprehensive evaluation problem of the ecological compensation effects for environmental pollution losses in Nanjing MV Industrial Park, this paper proposed a spatial niche evaluation; referred to the latest research results at home and abroad; taken into account the actual situation and requirements of the comprehensive evaluation of the ecological compensation effect for environmental 
pollution losses in the industrial park; improved and innovated based on the traditional niche suitability model, this paper constructed a spatial suitability model to provide comprehensive evaluation and application research on ecological compensation effect for environmental pollution losses in the Nanjing Industrial Park. The conclusions are as follows:

First, the overall trend of ecological compensation effect for environmental pollution losses in Nanjing MV Industrial Park is rising, but the effect at the criterion layer is uneven. Therefore, the management authorities of the industrial park should pay special attention to the imbalance of ecological strengthening management. 
compensation evaluation.

\section{Availability of data and materials}

452 Not applicable.

\section{Reference:}

Arrow K., Solow R., Portney P. R., Leamer E.E., Radner R., Schuman H., 1993. Report of the NOAA Panel on Contingent Valuation. Federal Register. 58, 4602-4614.

Barry C., Moore, Cox P. D., 1980.Biogeography: an ecological and evolutionary approach. Oxford University Press. 1980. DOI:10.1086/628353

Basille M., Calenge C., Marboutin É., Andersen R., Gaillard J. M., 2008. Assessing habitat selection using multivariate statistics: Some refinements of the ecological-niche factor analysis. Ecological Modelling. 211(1-2), 233-240.

Bundy A., Gomez C., Cook A.M., 2019. Scrupulous proxies: Defining and applying a rigorous framework for the selection and evaluation of a suite of ecological indicators. Ecological Indicators.2019, 104, 737-754.

Coughenour M. B., Ellis J. E., Swift D. M., Coppock D. L., Galvin K., McCabe J. T., Hart T. C., 1985. Energy extraction and use in a nomadic pastoral ecosystem. Science. 230, 619-624.

Cuperus R., Caters K. J., Piepers A. A. G., 1996. Ecological compensation of the impacts of a road: Preliminary method of ASO road link. Ecological Eingeering. (7), 327-349.

Deng J. R., Hong S. Q., Shi S. S.,2001 Ecological Compensation in Environment Assessment. Yunnan Environmental Science. (6), 1-3.

Du W. P., 2001. Suggestions on improving the ecological compensation mechanism in the western region. China Population, Resources and Environment. 11(3), 119-120.

Geussens K., Broeck G. V. D., Vanderhaegen K., Verbist B., Maertens M., 2019. Farmers' perspectives on payments for ecosystem services in Uganda. Land Use Policy. 2019, 84, 316-327.

Godsoe W., Jankowski J., Holt R. D., Gravel D., 2017. Integrating Biogeography with Contemporary Niche Theory. Trends in Ecology \& Evolution. 32(7), 488-499.

Gong F., Chen B.X., 2019. Study on Comprehensive Evaluation of Grassland Ecological Compensation Effect Based on DPSIR Model -- Taking Inner Mongolia as an Example. Journal of Inner Mongolia 
Agricultural University(Social Science Edrion) $\quad .21(5), 1-6 . \quad$ DOI : $\quad 10.16853 /$ j.issn.10094458.2019 .05 .001

Greco S., Ishizaka A., Tasiou M., Torrisi G., 2019. Sigma-Mu efficiency analysis: A methodology for evaluating units through composite indicators. European Journal of Operational Research. 278 (3), $942-960$.

Grima N., Singh S. J., Smetschka B., 2018. Improving payments for ecosystem services (PES) outcomes through the use of Multi-Criteria Evaluation (MCE) and the software OPTamos. Ecosystem Services. 29,47-55.

Guo W., Li W., 2014. Ecological Compensation of Transfer Payment Effect Assessment Based on Multivariate Statistical Analysis. On Economic Problems. (11),92-97.

Han X. Y., Sun T., Cao T. Y., 2021. Study on landscape quality assessment of urban forest parks: Take Nanjing Zijinshan National forest Park as an example. Ecological indicators. 120 (2021) 106902.

Han X. Y., Sun T., Feng Q., 2019. Study on environmental pollution loss measurement model of energy consumption emits and its application in industrial parks. Science of the Total Environment. 668, 1259-1266.

Han X. Y., Sun T., Gao M., 2018. Study on the New Urbanization Construction, Energy Consumption Growth and Carbon Emission Intensity Controlling. Soft Science. 32(9), 90-93.

Jin L. H., Liu J. H., Kong D. S., 2019. Evaluation of the incorporation of gross ecosystem product into performance appraisals for ecological compensation. Acta Ecologica Sinica. (1), 24-36.

Kelly M., Guo Q. H.,Liu D. S., Shaari D.,2007. Modeling the risk for a new invasive forest disease in the United States: An evaluation of five environmental niche models. Computers, Environment and Urban Systems. 31(6), 689-710

Li C., Yang Y. J., Liu S. F., 2019. Comparative analysis of properties of weakening buffer operators in time series prediction models. Communications in Nonlinear Science and Numerical Simulation. 68, 257285.

Liu H. M., Xu R. F., Zhang R. Y., 2008. Application model of Deng's grey correlation analysis. Statistics and Decision. (20), 23-25. DOI:10.13546/j.cnki.tjyjc.2008.10.022

Liu J. Y., Dou S. Q., 2020. Abdellahi El Housseine Hmeimar. Cost-effectiveness analysis of different types of payments for ecosystem services: A case in the urban wetland ecosystem. Journal of Cleaner Production. 249, 119325. 
Loft L., Gehrig S., Le D. N., Rommel J., 2019. Effectiveness and equity of Payments for Ecosystem Services: Real-effort experiments with Vietnamese land users. Land Use Policy. 86, 218-228.

Loomis J., Kent P., Strange L., Fausch K., Covich A., 2000. Measuring the total economic value of restoring ecosystem services in an impaired river basin: results from a contingent valuation survey. Ecological Economics. 33(1), 103-117.

Martín-López B., Felipe-Lucia M. R, Bennett E. M., Norström A., Locatelli B., 2019. A novel telecoupling framework to assess social relations across spatial scales for ecosystem services research. Journal of Environmental Management. 241, 251-263.

Müller F., 1997. State-of-the-art in ecosystem theory. Ecological Modeling. 100, (1-3), 135-161.

Ola O., Menapace L., Benjamin E., Lang H.,2019. Determinants of the environmental conservation and poverty alleviation objectives of Payments for Ecosystem Services (PES) programs. Ecosystem Services. 35, 52-66.

Qin L. L., Wang D. P., Zhou C.,2011. Sustainability assessment of regional innovation system based on synthetic niche-fitness. Systems Engineering - Theory\&Practice. 31(5), 927-935.

Shen K. L., Wang X. Y., Zhang Y. Y., 2018. Performance Evaluation on Ecological Compensation in Ecological Sheltered Ground. Ecological Economy. 34(6), 199-204.

Teng F.Q., 2020. Evaluation of ecological compensation effect in Daling River Basin.Technical Supervision in Water Resources.(4),143-146+158. DOI: 10. 3969/j. issn.1008-1305. 2020. 04. 040.

Wang H. M., Xu H. H., 2008. Conception of introducing ecological compensation into environmental impact assessment. Environmental Protection. (8), 23-25. OI:10.14026/j.cnki.0253-9705.2008.08.005.

Wang X. H., Berman E. M., Chen D. Y., Niu X. J., 2019. Strategies to improve environmental networks for pollution control: Evidence from eco-compensation programs in China. Journal of Environmental Management. 234, 387-395.

Wang X., Liu H. T., Wang Y. Y., 2013. Ecological Compensation Evaluation of Yongding South Industrial Park in Fujian Province. Journal of Anhui Agricultural Sciences. 41(21), 8950-8953.

Westman W. E., 1977. How Much Are Nature's Services Worth?. Science. 197(4307), 960-964. DOI: 10.1126/ science. 197.4307 .960

Xu D.W., Li B., 2015. Research on Regional Ecological Compensation Performance Appraisal Based on Propensity Score Analysis. China Population, Resources and Environment. (3), 58-64.

Yang K., Ding Y., Zhu N., Yang F., Wang Q. C.,2018. Multi-criteria integrated evaluation of distributed 
energy system for community energy planning based on improved grey incidence approach: A case study in Tianjin. Applied Energy. 229, 352-363.

Yang T., Xiao Y. D., Huang H.J. et al., Lai F., Chang Y., Pan Z., Xiao X., 2019. Assessment Optimization of the Contamination Degree and Ecological Risk of Heavy Metals in Sewage Sludge. Environmental Science \& Technology. 42(2),202-209.

Yousefi A., Ng T.T., 2017. Dimensionless input parameters in discrete element modeling and assessment of scaling techniques. Computers and Geotechnics. 88, 164-173.

Zeng X. G., Duan C. R., Yu H. Y., 2019. Influence mechanism of social capital on ecological compensation performance-A case on grassland ecological compensation in Xilin Gol League. China Environmental Science. 39(2), 879-888.

\section{Ethical Approval,}

Not applicable.

\section{Consent to Participate,}

Not applicable.

\section{Consent to Publish,}

All the authors agree to publish this paper in this journal.

\section{Authors Contributions,}

This paper was written by two authors. This paper was designed and written by Associate Professor Han Xiuyan. Dr. Tianyi Cao participated in data analysis and model calculation. The authors ranked according to their contributions.

\section{Competing Interests,}

This paper is completed by three authors, and there is no conflict of interest with any unit or individual. Other references have been noted and confirmed in this paper.

\section{Acknowledgements}

The author thanks the National Office for philosophy and Social Sciences for its financial 
563 support, and thank the experts for their review.

\section{Funding}

565 This work has received funding from the general project of national social science foundation

566 of China: "Research on mechanism and supportive polices of environmental pollution

567 cooperative governance in the process of regional integration development of the Yangtze

568 river delta" (Approval number: 19BJL035). 
Figures

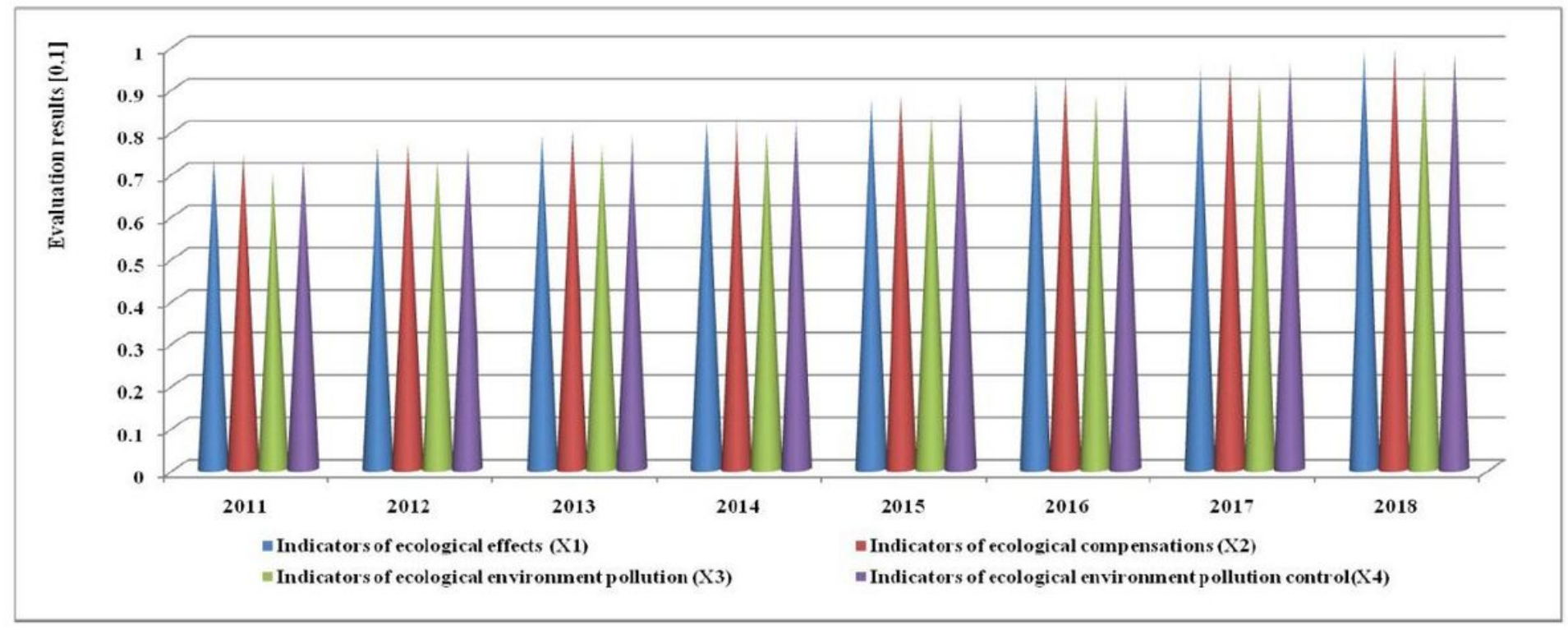

\section{Figure 1}

Change rule and interrelation diagram of the results of ECEE of environmental pollution loss in Nanjing MV Industrial Park

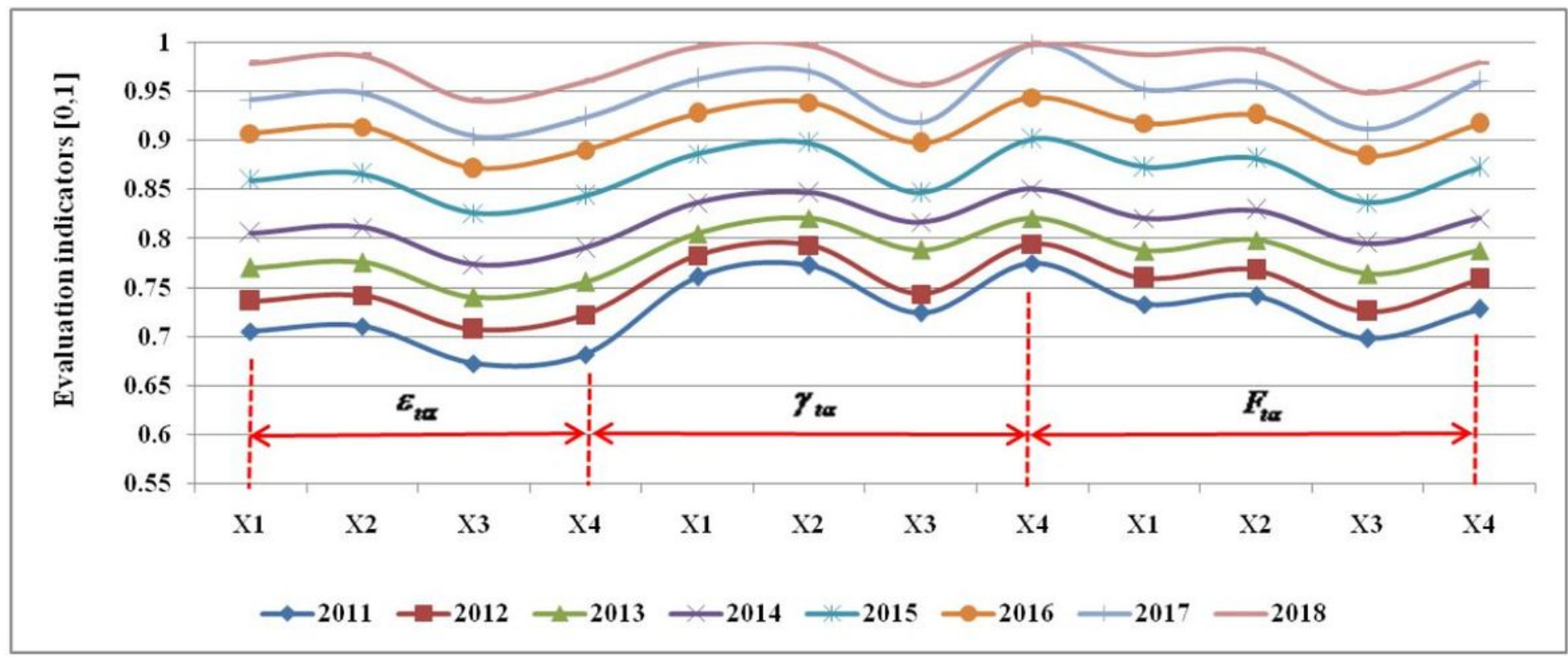

Figure 2

The change trend chart of the influencing factors of the ecological compensation effect of the environmental pollution loss in Nanjing MV Industrial Park 


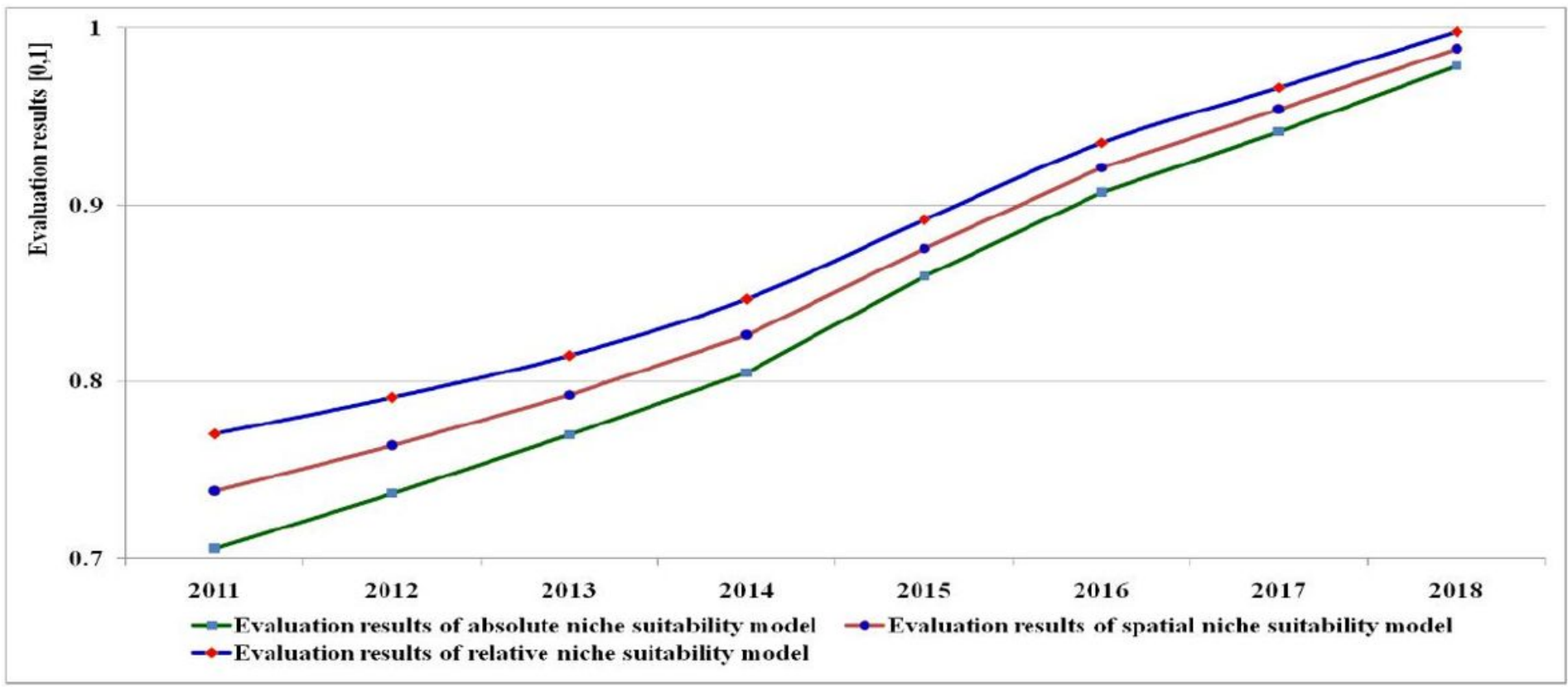

\section{Figure 3}

Change trend and interrelation chart of evaluation results of different evaluation models 